Gulawentah: Jurnal Studi Sosial

ISSN 2528-6293 (Print); ISSN 2528-6871 (Online)

Vol. 5, No. 1, Juni 2020, Hal 60-67

Tersedia Online: http://e-journal.unipma.ac.id/index.php/gulawentah

\title{
Keaktifan Siswa dalam Pembelajaran Geografi dengan Menggunakan Model Pembelajaran Reciprocal Teaching
}

\author{
Ulfi Andrian Sari \\ Jurusan Pendidikan Ilmu Pengetahuan Sosial, UIN Malik Ibrahim Malang, Jl. Gajayana No.50 \\ Kota Malang 65144, Indonesia \\ Email: ulfiandriansari@uin-malang.ac.id
}

Naskah diterima: 21/5/2020; Revisi: 31/5/2020; Disetujui: 4/6/2020

\begin{abstract}
Abstrak
Penelitian ini bertujuan untuk meneliti keaktifan siswa dalam pembelajaran geografi mengunakan model pembelajaran Reciprocal Teaching (RT). Subyek penelitain siswa SMAN 1 Kademanagan kelas X.6. Jumlah subyek penelitian 30 Siswa. Metode penelitian menggunakan metode deskriptif kualitatif. Instrumen penelitian berupa lembar observasi dengan menggunakan skala likert. Analisis data menggunakan rumus prosentase. Hasil penelitian keaktifan siswa dalam pembelajaran geografi untuk indikator visual activitie sebesar $86 \%$ termasuk kategori baik, writing activities sebesar 95\% termasuk kategori sangat baik, oral activities sebesar $83 \%$ termasuk kategori baik, mental activities sebesar $82 \%$ termasuk kategori baik, listening activities sebesar $67 \%$ termasuk kategori cukup dan emotional activities sebesar $90 \%$ termasuk kategori sangat baik.
\end{abstract}

Kata kunci: keaktifan siswa; reciprocal teaching

\section{Student Activity in Geography Learning using Reciprocal Teaching Learning Model}

\section{Abstract}

This study aims to examine the activeness of students in learning geography using the Reciprocal Teaching (RT) learning model. The research subjects were students of SMAN 1 Kademanagan, class X.6. The number of research subjects is 30 students. The research method uses a qualitative descriptive method. The research instrument was in the form of an observation sheet using a Likert scale. Data analysis uses the percentage formula. The results of the students' study of geography in learning geography showed that visual activity indicators were $86 \%$ included in the good category, writing activities by $95 \%$ included in the excellent category, oral activities by $83 \%$ including the good category, mental activities by $82 \%$ including the good category, listening activities for $67 \%$ included in the moderate category and emotional activities by $90 \%$ included in the excellent category.

Keywords: student activity; reciprocal teaching

\section{Pendahuluan}

Pembelajaran harus berpusat pada aktifitas siswa. Siswa harus aktif dalam pembelajaran, jika aktivitas siswa rendah pembelajaran tidak akan berjalan dengan baik. Keaktifan siswa saat pembelajaran menjadi salah satu indikator keberhasilan pembelajaran. Pembelajaran yang diselenggarakan oleh satuan pendidikan diselenggarakan secara interaktif,

DOI: 10.25273/gulawentah.v5i1.6597

Some rights reserved. 
inspiratif, menyenangkan, menantang, memotivasi peserta didik untuk berpartisipasi aktif, serta memberikan ruang yang cukup bagi prakarsa, kreativitas, dan kemandirian sesuai dengan bakat, minat, dan perkembangan fisik serta psikologis peserta didik (Permendikbud Nomor 22 2016).

Tidak ada pembelajaran, jika tidak ada aktivitas yang dilakukan oleh siswa. Pada prinsipnya pembelajaran adalah melakukan kegiatan untuk mengubah tingkah laku (Sardiman 2014). Aktifitas dapat diartikan kegiatan yang dilakukan oleh siswa saat mengikuti pembelajaran baik di kelas maupun dalam kehidupan sehari-hari. Aktivitas merupakan kegiatan mengaplikasikan pengetahuan, sikap dan keterampilan dalam pembelajaran. Pengetahuan tersebut harus diperoleh melalui pengamatan sendiri, pengalaman sendiri, penyelidikan sendiri, dengan fasilitas yang ada.

Geografi sering disebut matapelajar yang membosankan, karena banyak menghafal hal ini menyebabkan aktivitas belajar geografi rendah (Apriyanto et al. 2017; Rivai and Wulandari 2018; Susilawati 2016). Akan tetapi guru Geografi di SMAN 1 Kademangan menerapakan pembelajaran RT. Pembelajaran dengan model RT digunakan pada materi-materi yang berisi konsep pada level koknitif C1-C3. Observasi awal saat mengikuti guru mengajar dikelas siswa antusias dalam mengikuti pembelajaran dan tidak bosan. Padalah biasanya siswa sering bosan belajar geografi saat materi pelajaraannya berisi konsep.

Reciprocal Teaching (RT) merupakan salah satu model pembelajan yang dapat mengembangkan aktivitas belajar siswa. $R T$ dikembangkan oleh Palincsar dan Brown untuk memberbaiki aktivitas siswa dalam pembelajaran (Palincsar \& Brown 1983). Pembelajaran $R T$ dilakukan dengan kegiatan siswa membaca, menyusun pertanyaan, mengklarifikasi, merangkum dan memprediksi materi. Pembelajaran $R T$ merupakan dialog antara guru dengan siswa dalam memahami isi teks, yang dipelajari dengan melakukan kegiatan merangkum, menyusun pertanyaan, klarifikasi, dan prediksi yang dapat meningkatkan kemampuan kognitif siswa (Doolittle et al. 2006; Oczkus 2003; Padma 2008; Slavin 2008).

Tahapan penting dalam pembelajaran RT. Ppertama, siswa membuat rangkuman. Kegiatan merangkum didahului dengan membaca materi yang akan dipelajarai. Kemudian, siswa memberi garis bawah ide pokok yang penting dalam setiap paragraph untuk dijadikan rangkuman. Menurut Oczkus (2010) kegiatan merangkum bertujuan untuk mengidentifikasi informasi penting dalam teks". Siswa menjadi lebih mudah memahami materi karena telah menemukan informasi-informasi penting di dalam teks. Kedua, siswa membuat pertanyaan. Siswa membuat pertanyaan untuk menggali informasi dan memecahkan gagasan dari teks yang belum dipahami (Nurhadi et al. 2004). Menyusun pertanyaan merupakan usaha mengembangkan rasa ingin tahu untuk memperoleh berbagai informasi. Tujuan membuat pertanyaan untuk meningkatkan kemampuan berpikir siswa (Oczkus 2010). Ketiga, siswa membuat klarifikasi dari jawaban temannya. Klarifikasi merupakan kegiatan mengkritisi dan menilai jawaban dari pertanyaan yang telah dibuat untuk memecahkan masalah yang dihadapi ketika membaca materi (Padma 2008). Kemampuan siswa mengkarifikasi jawaban diukur dari tanggapan siswa dalam merevisi dan menilai jawaban temannya. Siswa yang mampu memberi tanggapan sesuai konsep yang dipelajari, berarti mereka telah memahami materi. Keempat, siswa membuat prediksi. Kegiatan memprediksi dengan membuat ramalan tentang materi yang akan dipelajari selanjutnya. Tujuan memprediksi agar siswa termotivasi untuk membaca dan mempelajari materi yang akan dibahas selanjutnya (Stricklin 2011). Siswa yang sudah membaca materi sebelum pelajaran dimulai akan lebih mudah dan cepat menerima pelajaran yang disampaikan oleh guru.

Pembelajaran $R T$ memiliki banyak keungulan karena dalam pembelajaran ini menggunakan empat kegiatan untuk memahami bacaan. Kegitan merangkum, menyusun pertanyaan, klarifiksai dan prediksi yang diterapkan dengan baik dapat keaktifan, motivasi, kearif dan mandiri dalam belajar (Palincsar \& Brown 1984). Alasan guru geografi di SMAN 1 Kademangan menggunakan RT karena dapat menumbuhkan keaktifan siswa dibandingkan dengan pembelajaran ceramah pada materi yang berisi konsep. 
Penelitian terdahulu yang pernah dilakukan oleh (Vahlia \& Sudarman 2015) pembelajaran RT dapat meningkatkan aktivitas belajar. Senada dengan penelitian yang dilakukan oleh (Susanti 2014) Pmebelajaran RT efektif untuk memperebaiki keaktifan siswa yang kurang. Pendapat yang sama juga ditemukan pada penelitian (Utomo \& Suwito 2017) penerapan model RT dapat aktivitas belajar.

Penelitian ini memiliki persamaam dan perbedaan dengan penelitian sebelumnya. Persamaan penelitian ini dengan tiga peneliti sebelumnya sama-sama meneliti variabel model pembelajaran RT dan keaktifan siswa. Penelitian ini berbeda dengan penelitian sebelumnya karena menggunakan metode deskriptif kuantitatif, sedangkan penelitian sebelumnya menggunkan PTK. Penelitian ini hanya fokus mengamati keaktifan siswa saat mengikuti pembelajaran dengan menggunakan model RT.

\section{Metode Penelitian}

Penelitian ini dilaksanakan di kelas X.6 SMAN 1 Kademangan, Kabupaten Blitar. Penelitian ini dilaksakan selama dua bulan mulai bulan maret sampai april. Penelitian ini untuk mendeskripsikan bagaimana aktivitas siswa saat pembelajaran menggunakan model pembelajran RT yang biasa diterapkan oleh guru di sekolah. Materi pembelajaran yang disampaikan guru berisi konsep C1 sampai C2 pada materi atmosfer. Metode penelitiannya menggunakan kualitatif deskriptif. Subyek penelitian kelas X.6, yang berjumlah 30 siswa.

Data keaktifan belajar siswa menggunkan model RT diperoleh dari lembar observasi keaktifan siswa. Teknik pengumpulan data menggunkan lembar observasi yang diisi oleh observer. Instrumen aktivitas belajar siswa didesain menggunkan skala likert dengan skor 1 sampai 5. Instrument aktivitas siswa yang terdiri dari 6 indikator. Menurut Paul B. Diedrich indikator aktivitas belajar terdiri dari 8 indikator, akan tetepi penelitian ini menyesuakan dengan model RT yang mengambil 6 indiktor. Indikator tersebut 1) visual activitie, 2) oral activities, 3) listening activities, 4) writing activities, 5) mental activities dan 6) emotional activities (Diederich, 1966).

Pada penelitian ini analisis data menggunakan rumus persentase. Rumus persentase keaktifan siswa sebagai berikut.

$$
\text { Keaktifan siswa }=\frac{\Sigma \text { Skor yang diperoleh siswa }}{\Sigma \text { Skor maksimal }} \times 100
$$

Kriteria untuk mengetahui seberapa banyak siswa yang aktif di dalam kelas, dibuat tabel kriteria keaktifan belajar siswa sebagai berikut

Tabel 1 Kriteria keaktifan belajar siswa

\begin{tabular}{cc}
\hline Persentase Keaktifan & Taraf Keberhasilan \\
\hline $85-100$ & Sangat Baik \\
\hline $70-84$ & Baik \\
\hline $55-69$ & Cukup \\
\hline $40-54$ & Kurang \\
\hline $0-39$ & Sangat Kurang \\
\hline
\end{tabular}

Sumber (Rusyiana \& Irmawan 2015)

\section{Hasil dan Pembahasan}

Penelitian ini mendeskripsikan aktivitas belajar siswa menggunkan model pembelajaran RT. Indikator untuk mengukur aktivitas diantaranya 1) visual activitie, 2) oral activities, 3) listening activities, 4) writing activities, 5) mental activities dan 6) emotional activities. Hasil dari penelitian berdasarkan persentase keaktifan siswa sebagai berikut

Tabel 2 Persentase keaktifan siswa di kelas

\begin{tabular}{ccc}
\hline Indikator & Persentase Keaktifan & Kriteria \\
\hline
\end{tabular}




\begin{tabular}{ccc}
\hline Visual activitie & 86 & Baik \\
\hline Writing activities & 95 & Sangat Baik \\
\hline Oral activities & 83 & Baik \\
\hline Mental activities & 82 & Baik \\
\hline Listening activities & 67 & Cukup \\
\hline Emotional activities & 90 & Sangat Baik \\
\hline \multicolumn{2}{c}{ Sumber $:$ Data hasil observasi di kelas }
\end{tabular}

Sumber : Data hasil observasi di kelas

Keaktifan siswa dari indikator visual activitie merupakan kegiatan membaca materi pelajaran. Kriteria keaktifan siswa dikelas tergolong baik. Pada pembelajaran RT siswa diharapkan untuk membaca materi pembelajaran atmosfer. Kegiatan membaca sangat penting dalam pembelajaran $R T$. Pembelajaran $R T$ berpusat pada aktivitas membaca. Siswa yang dilatih secara konsisten untuk membaca dapat memiliki kemampuan membaca yang tinggi. Siswa yang belajar menggunakan pembelajaran $R T$ memiliki kemampuan membaca buku pelajaran geografi dan atrikel pemanasan global. Rata-rata kemampuan membaca siswa yaitu 90.8 KPM (Kata Per Menit).

Kemampuan membaca buku berpengaruh terhadap penyelesaian belajar (Dimyati \& Mudjiono 2009). Siswa yang memiliki kemampuan membaca tinggi, kemampuan memahami konsepnya juga tinggi (Slavin 2008). Siswa yang memiliki kemampuan membaca diatas ratarata dalam kegiatan pembelajaran dengan mudah dapat menyesuaikan diri untuk menyelesaikan tugasnya. Semakin sulit tugas yang diberikan, siswa merasa tertantang untuk mencari jawabannya.

Tahapan kedua dari pembelajaran RT setelah membaca materi adalah membuat rangkuman dari materi yang telah dibaca. Indikator writing activities pada penelitian ini tergolong baik. Semua siswa membuat rangkuman dengan baik. Kemampuan siswa dalam merangkum untuk menemukan sesuatu merupakan keterampilan yang penting (Slavin 2008). Siswa dituntut memahami dan menganalisis ide-ide dalam teks sebelum merangkum. Kegiatan merangkum dapat mendorong siswa untuk menemukan informasi penting yang disajikan dalam teks. Siswa terlatih untuk menemukan hal-hal penting dari apa yang dipelajari.

Pembelajaran dengan merangkum akan membuat siswa belajar memahami konsepkonsep dengan lebih cepat. Siswa dapat menciptakan konteks untuk mengingat dan memahami secara spesifik dari sebuah teks dengan kegiatan merangkum (Oczkus 2010). Divesta (1976) dan Dansereau (1978) (dalam Degeng 2013) mengemukakan bahwa siswa-siswa yang diajar atau disuruh membuat rangkuman tentang apa yang telah dibaca, memperlihatkan unjuk kerja yang lebih baik dalam tes mengingat isi teks dari pada mereka yang hanya membaca teks berulang-ulang tanpa membuat rangkuman .

Siswa akan lebih mudah membaca kembali rangkumannya jika mereka lupa dengan materi yang telah dipelajari, dari pada harus membaca teks yang panjang. Eksperimen yang dilakukan oleh Reder dan Anderson (1980) (dalam Degeng 2013) menyimpulkan bahwa membaca rangkuman dari teks lebih efektif dari pada membaca teks aslinya. Siswa yang sebelum belajar, membaca rangkuman tentang konsep yang telah dipelajari, memperlihatkan hasil belajar yang lebih baik dari pada siswa yang langsung membaca keseluruhan teks (Marrill \& Stolurow 1966).

Indikator yang ke tiga oral activities yang merupakan kegiatan membuat pertanyaan. Kegiatan oral aktivitas pada pembelajaran RT terdapat pada sintak membuat pertanyaan. Siswa didorong untuk mengidentifikasi makna penting dari teks dan menghasilkan pertanyaan saat membaca. Menyusun pertanyaan dapat menumbuhkan rasa ingin tahu untuk memperoleh informasi. Sebelum siswa berhasil membuat pertanyaan, mereka akan mencari informasi yang belum dipahami untuk dijadikan pertanyaan.

Kegiatan menyusun pertanyaan dapat membuat siswa memperoleh informasi yang lebih banyak (Nurhadi et al. 2004). Senada dengan pendapat Stricklin (2011) melalui kegiatan 
membuat pertanyaan dapat diketahui sejauh mana siswa paham dengan apa yang dipelajari. Jika siswa memiliki kemampuan berpikir yang baik dalam membuat dan menanggapi pertanyaan akan dapat meningkatkan prestasi belajar siswa (Eggen and Kauchak 2012).

Mental activities menangapi jawaban dari teman dengan mengklarifikiasi jawaban. Indikator mental activities tergolong baik. Sintak pembelajaran RT yang ke 3 siswa mengklarifikasi jawaban dari temannya. Klarifikasi merupakan hasil mengevaluasi secara kritis jawaban dari temannya. Kemudian memberikan nilai dan komentar serta alasan mengapa jawabannya benar atau salah. Kemampuan siswa dalam mengklarifikasi jawaban dapat diukur dari cara siswa mengomentari dan merevisi jawaban temannya. Klarifikasi jawaban diukur dari tanggapan siswa dengan menandai kesalahan dan kemudian merevisi serta menambahkan jawaban yang benar. Siswa yang tidak menemukan jawaban pada sesi klarifikasi akan mencari sumber lain yang mendukung jawabannya.

Siswa mampu mengomentari dan merevisi jawaban sesuai dengan konsep yang dipelajari. Klarifikasi dapat memberikan motivasi kepada siswa untuk menemukan dan mengoreksi jawaban melalui kegiatan membaca teks. Siswa yang memiliki motivasi untuk belajar akan berusaha memahami materi karena mereka tertarik dan bisa juga siswa ingin mendapatkan nilai yang bagus (Eggen \& Kauchak 2012).

Indikator emotional activities dapat dilihat dari motivasi siswa yang tinggi saat mengikuti pelajaran. Keaktifan siswa dapat dipengaruhi oleh motivasi belajar siswa. Kegiatan memprediksi yang merupakan sintak ke empat pembelajaran RT dapat membuat siswa termotivasi dan penasaran dengan materi selanjutnya yang kan dipelajarai. Siswa memprediksi materi yang akan dipelajari selanjutnya. Prediksi terdiri dari penggabungan pengetahuan awal dan pengetahuan baru siswa yang didapat dari teks, untuk meramalkan isi dari bacaan selanjutnya. Siswa dapat mencari informasi untuk membuat prediksi yang logis sebelum dan selama kegiatan membaca teks.

Kegiatan memprediksi mendorong siswa untuk berpikir ke depan (Reilly \& Yvonne, 2009). Siswa akan lebih terbuka dalam menerima informasi baru. Siswa akan terbiasa mengantisipasi dan membuat ramalan tentang segala hal yang akan terjadi diwaktu mendatang berdasarkan informasi yang telah diterima.

Prediksi dapat memotivasi siswa untuk terus membaca, karena siswa penasaran apakah prediksi awal mereka adalah benar atau salah. Motivasi belajar yang rendah berpengaruh terhadap pemahaman siswa dalam menerima pemahaman materi yang diajarkan guru. Motivasi dan prestasi saling terkait, segala sesuatu yang bisa mendorong motivasi akan berkontribusi terhadap pembelajaran (Eggen \& Kauchak 2012).

Siswa mempresentasikan hasil kerja kelompoknya temasuk dalam kegiatan oral dan mental activities. Karena siswa menyampakian hasil pekerjaannya didepan kelas dan hanya siswa yang percaya diri yang memiliki mental yang mampu memprentasikan hasil pekerjaannya di depan kelas. Siswa mempresentasikan hasil kerja kelompok di depan teman-temanya. Siswa dari kelompok lain akan mengajukan pertanyaan tentang materi yang tidak dimengerti kepada kelompok yang presentasi. Hasil presentasi akan dikomentari dan dinilai oleh kelompok lain dan guru. Prosedur ini dapat membantu siswa mengembangkan sikap sosial dan saling menghargai pendapat orang lain (Slavin, 2010). Selain itu juga melatih keberanian siswa mengajukan pendapat dan menjawab pertanyaan dari audients.

Kegiatan presentasi bertujuan untuk mengukur keberhasilan kerja kelompok. Siswa yang bekerja dengan kelompoknya dan saling memiliki ketergantungan positif akan lebih cepat menyelesaikan tugasnya. Mereka juga lebih cepat dalam memahami meteri, karena ada pertukaran pendapat antar anggota kelompok. Keberhasilan kelompok juga diukur dari kemampuan siswa dalam menjawab pertanyaan dari teman (Eggen \& Kauchak 2012). Siswa yang mampu menjawab pertanyaan dengan baik, hasil belajarnya juga akan tinggi. Siswa yang mampu menjawab pertanyaan dengan benar, membuktikan bahwa mereka memahami materi.

Indikator selanjutnya listening activities yang merupakan kegiatan mendengarkan, diskusi. Indikator mendengarkan presentasi dari teman tergolong cukup. Berdasarkan pengamatan beberapa siswa yang kurang mendengarkan temannya saat presentasi. Hal ini 
disebabkan siswa ingin cepat pulang, karena pembelajaran dilaksankan pada akhir jam pelajaran. Walaupun demikian siswa masih menanggapi pertanyaan dan menyanggah jawaban yang salah dari temannya.

\section{Simpulan}

Keberhasilan dalam pembelajaran salah satu indikatornya terletak pada aktivitas belajar siswa. Pembelajaran dengan model RT terbukti dapat mengembangkan keatifan siswa dalam pembelajaran geografi dari segi visual activitie, writing activities, oral activitie, mental activities, listening activities dan emotional activitie. Sintak dalam pembelajaran RT yang terdiri dari empat tahapan yaitu merangkum, mebuat pertanyaan, klarifikasi dan prediksi. Adapun tambahan sintak sebagai modifikasi model pembelajaran RT siswa harus membaca materi terlebih dahulu sebelum membuat rangkuman dan siswa mempresentasikan hasil rangkumannya. Sintak tersebut yang menyebabkan keaktifan siswa dapat berkembang dengan baik.

\section{Daftar Pustaka}

Apriyanto, B., Nurdin, E. A., Ikhsan, F. A., and Kurniawan, F. A. (2017). Penerapan Pembelajaran Berbasis Masalah untuk Meningkatkan Aktivitas dan Hasil Belajar Siswa dalam Memahami Lingkungan Hidup Pada Mata Pelajaran IPS Di SMP Negeri 2 Sukodono. Jurnal Pendidikan Ekonomi: Jurnal Ilmiah Ilmu Pendidikan, Ilmu Ekonomi dan Ilmu Sosial, 11(2), 8-13.

Degeng, N. (2013). Ilmu Pembelajaran (Klasifikasi Variabel Untuk Pengembangan Teori Dan Penelitian). Bandung: Kalam Hidup.

Dimyati, D and Mudjiono, M. (2009). Belajar Dan Pembelajaran. Jakarta: Rineka Cipta.

Doolittle, Peter E., David Hicks, Cheri F. Triplett, William Dee Nichols, and Carl A. Young. (2006). Reciprocal Teaching for Reading Comprehension in Higher Education: A Strategy for Fostering the Deeper Understanding of Texts. International Journal of Teaching and Learning in Higher Education. 17(2), 106-18.

Eggen, and Kauchak. (2012). Strategi Dan Model Pembelajaran. Jakarta: PT Indeks.

Marrill, and Stolurow. (1966). Hierarchical Preview Vs. Problem Oriented Review in Learning on Imaginary Science. America Education Research Journal 3(4).

Nurhadi, dkk, dkk, and dkk. (2004). Pembelajaran Kontekstual Dan Penerapannya Dalam KBK. Malang: Universitas Negeri Malang.

Oczkus. (2003). Reciprocal Teaching at Work: Strategies for Improving Reading Comprehension. New York: International Reading Association. 
Oczkus. (2010). Reciprocal Teaching at Work: Powerful Strategies and Lessons for Improving Reading Comprehension. New York: International Reading Association.

Padma. (2008). Reciprocal Teaching Techniques. New Delhi: S.B Nangia.

Palincsar, and Brown. (1983). Reciprocal Teachingof Comprehension Monitoring Activities. Champaign-Urban: University of Illinois.

Palincsar, and Brown. (1984). Reciprocal Teaching of Comprehension-Fostering and Comprehension-Monitoring Activities. Journal The Reading Teacher, 1(2), 117-75.

Permendikbud Nomor 22. (2016). Tentang Standar Proses Pendidikan Dasar Dan Menengah. Jakarta: Kementrian Pendidikan dan Kebudayaan Republik Indonesia.

Rivai, Immawati Nur Aisyah, and Taat Wulandari. (2018). Perbedaan metode debat dan ceramah terhadap penguasaan konsep IPS ditinjau dari berpikir kritis siswa. Harmoni Sosial: Jurnal Pendidikan IPS, 5(1), 1-11.

Rusyiana, Novrika, and Rofiq Irmawan. (2015). Meningkatkan Aktivitas Belajar dan Hasil Belajar Siswa dengan Penerapan Model Pembelajaran Mind Mapping. Jurnal Pendidikan Bisnis dan Manajemen, 1(2), 86-99.

Sardiman. (2014). Interaksi Dan Motivasi Belajar Mengajar. Jakarta: Rajawali Press.

Slavin. (2008). Psikologi Pendidikan Teori Dan Praktik Jilid 1. Jakarta: PT Indeks.

Slavin. (2010). Cooperative Learning: Teori, Riset Dan Praktik. Bandung: Nusa Media.

Stricklin, K. (2011). Hands-On Reciprocal Teaching: A Comprehension Technique. Journal The Reading Teacher, 64(8), 620-25.

Susanti, V. D. (2014). Efektivitas Metode Reciprocal Teaching Ditinjau dari Keaktifan Siswa terhadap Prestasi Belajar Matematika Siswa Kelas X SMA Kyai Ageng Basyariyah Sewulan Dagangan Tahun Ajaran 2012/2013. JIPM (Jurnal Ilmiah Pendidikan Matematika), 3(1).

Susilawati, S. (2016). Cara Memilih Strategi Pembelajaran Geografi Dalam Kurikulum 2004. Jurnal Geografi Gea, 6(2).

Utomo, N. S., and Suwito, D. (2017). Pendekatan Model Pembelajaran Reciprocal Teaching Untuk Meningkatkan Aktivitas Dan Hasil Belajar Siswa Pada Kompetensi Dasar Mesin Tenaga Fluida Kelas X TPM 2 SMK Negeri 3 Surabaya. JPTM, 6(1),105-11. 
Vahlia, Ira, and Satrio Wicaksono Sudarman. (2015). Penerapan Model Pembelajaran Berbalik (Reciprocal Teaching) Ditinjau Dari Aktivitas Dan Hasil Belajar Siswa. Aksioma ,4(1),59-66. 